Izabela Bawej

Uniwersytet Kazimierza Wielkiego, Bydgoszcz

\title{
HELENE DECKE-CORNILL, LUTZ KÜSTER FREMDSPRACHENDIDAKTIK. EINE EINFÜHRUNG. NARR VERLAG, TÜBINGEN 2010, 291 ss. Omówienie publikacji
}

Nakładem niemieckiego wydawnictwa Narr Verlag ukazała się w roku 2010 pozycja pt. Fremdsprachendidaktik. Eine Einführung dwóch badaczy o bogatym dorobku metodycznym: profesor Helene Decke-Cornill z Uniwersytetu w Hamburgu specjalizującej się $w$ dydaktyce nauczania języka angielskiego jako języka obcego i profesora Lutza Küstera z Uniwersytetu Humboldtów w Berlinie zajmującego się dydaktyką nauczania języków romańskich.

Jest to niezwykle interesująca pozycja, którą można potraktować jako rodzaj podręcznika i poradnika metodycznego. Autorzy postawili sobie za cel przedstawienie w sposób możliwie przystępny i jak najbardziej wyczerpujący wybranych zagadnień z zakresu teorii i praktyki glottodydaktycznej.

Publikacja jest adresowana do szerokiego kręgu studentów kierunków neofilologicznych uczących się języka niemieckiego, specjalistów w zakresie glottodydaktyki, nauczycieli języka niemieckiego wszystkich szczebli w szkołach różnego typu oraz wszystkich tych, którzy interesują się problematyką kształcenia językowego i znają w stopniu biegłym język niemiecki. Teoretycy znajdą tu syntezę wiedzy dotyczącą zagadnień związanych z procesami nauczania i uczenia się języków obcych. Należy jednak podkreślić, iż Autorzy pracy nie ograniczają swoich rozważań do obszaru edukacji językowej w warunkach zinstytucjonalizowanych. Studentom niniejsza praca pozwoli poznać i lepiej zrozumieć najbardziej aktualne problemy teorii i praktyki glottodydaktycznej, a dla nauczycieli-praktyków będzie ona inspiracją do ciągłego poszukiwania coraz bardziej doskonałych rozwiązań na swoich lekcjach. 
Uważam także, iż pozycja ta jest cenną pomocą dla nauczycieli akademickich prowadzących zajęcia np. z metodyki nauczania języka niemieckiego.

Niniejsza publikacja składa się ze wstępu (str. XI), 14 rozdziałów (str. 1-262), posłowia (str. 263), obszernej bibliografii (str. 265), indeksu zawartych w niej terminów (str. 287) oraz wykazu ilustracji (str. 291).

Każdy rozdział zaczyna się krótkim wprowadzeniem w problematykę danej jednostki, a kończy streszczeniem. Po każdym rozdziale umieszczono zadania dotyczące podejmowanej w nim tematyki. Znajdziemy wśród nich ćwiczenia, które można wykonać, wchodząc na wyszczególnione w nich strony internetowe, co jest według mnie ciekawym sposobem pracy, zwłaszcza w dobie komputeryzacji i zamiłowania wielu osób do korzystania ze wszystkich nowości. Należy podkreślić, iż polecenia sformułowane są jasno i zrozumiale. W tym kontekście nie bez znaczenia jest również fakt, iż cała publikacja została napisana w przystępny sposób. Podane informacje są uzupełnione licznymi, ale bardzo przejrzystymi schematami, tabelami, wykresami i zdjęciami. Dodatkowy materiał dotyczący wybranych zagadnień znajdziemy na stronie internetowej wydawnictwa pod adresem www.bachelor-wissen.de, o czym Czytelnik jest informowany za pomocą widniejącego na marginesie symbolu lampki.

$\mathrm{Na}$ uwagę zasługuje również to, iż po każdym rozdziale jako uzupełnienie omawianego materiału Autorzy podają propozycje niemiecko- $\mathrm{i}$ angielskojęzycznej literatury (artykuły oraz prace o charakterze monograficznym) służącej pogłębieniu rozpatrywanej problematyki.

Rozdział 1 - Fremdsprachendidaktik - was ist das? Zur Verortung der Disziplin - (str. 1-20) poświęcony jest charakterystyce glottodydaktyki jako dyscypliny naukowej i określeniu jej statusu metodologicznego. Autorzy wyjaśniają na przykład, skąd pochodzi nazwa glottodydaktyka, podają przedmiot, cele i metody badań tej dyscypliny oraz jej związki z innymi naukami. Nie pomijają przy tym podstawowych terminów naukowych z zakresu dydaktyki języków obcych (glottodydaktyki), bez których znajomości niemożliwa jest dalsza lektura tej książki oraz zalecanej literatury.

Rozdział 2 - Spracherwerbstheorien - (str. 21-38) dotyczy wybranych teorii akwizycji języka pierwszego i dalszych języków. W przystępny sposób scharakteryzowano m.in. behawiorystyczną, natywistyczną oraz kogitywnokonstruktywną teorię akwizycji języka. Warto dodać, iż Autorzy bardzo dokładnie opisują przy tym zagadnienia związane m.in. z reakcją na poglądy behawiorystów, najważniejszymi założeniami hipotezy kontrastywnej, hipotezy o interjęzyku, w tym problemu błędów językowych w procesie nauki języka obcego, teorii uczenia się według Piageta, rozróżnienia terminologicznego akwizycja a uczenie się, kompetencja a realizacja językowa. Uważam za słuszne 
omówienie tych zagadnień teoretycznych w celu zorientowania Czytelnika w wielu sprawach ogólnych związanych z praktyką glottodydaktyczną.

W kolejnym rozdziale (rozdział 3) - Kognition und Emotion beim Sprachlernen - (str. 39-54) poruszono kwestię kognitywizmu oraz stanów emocjonalnych towarzyszących uczeniu się. Autorzy przedstawiają proces nauki jako proces uczenia się kognitywnego i słusznie podkreślają, że emocje stanowią obok procesów kognitywnych i motywacyjnych istotny aspekt zachowania językowego w trakcie przetwarzania informacji przez uczącego się, na przykład informacji w języku obcym. Korzystając z obrazowego schematu, w przystępny sposób wyjaśniają przy tym definicje wiedzy strategicznej, deklaratywnej, proceduralnej oraz metakognitywnej. Znaczna część rozdziału poświęcona jest znaczeniu uczuć i emocji w procesie nauki języka obcego. Na szczególną uwagę zasługuje podrozdział, w którym omówiono rolę emocji w procesie komunikacji językowej, zwłaszcza tej prowadzonej w języku obcym oraz część przedstawiająca zagadnienia związane z motywacją jako połączeniem czynników kognitywnych i afektywnych, z rodzajami motywacji oraz wybranymi elementami teorii motywacji.

W rozdziale 4 - Zur bildungspolitischen Geschichte des Fremdsprachenunterrichts - (str. 55-74) naszkicowano historię nauczania języków obcych, przedstawiono rolę średniowiecznej łaciny oraz scharakteryzowano stosunek do nauki w wybranych epokach i związane z tym implikacje dla rozwoju językowego ludzi, początki pierwszych lekcji języków obcych, obraz nauczania języków w XIX wieku, na początku wieku XX i po II wojnie światowej, a także problem wyboru właściwej metody nauczania języków nowożytnych.

Rozdział 5 - Konzeptionen des Fremdsprachenunterrichts - (str. 75-92) obejmuje zagadnienia związane z koncepcją zajęć z języka obcego według modelu: co, jak, dlaczego? Wyjaśniono bardzo dokładnie definicję metody nauczania, przedstawiono rodzaje metod i omówiono pięć aspektów modeli lekcji języka obcego. W dalszej kolejności scharakteryzowano konwencjonalne metody nauczania, z którymi można się spotkać w codziennej praktyce, tj. metodę gramatyczno-tłumaczeniową, bezpośrednią, audiolingwalną i audiowizualną oraz podejście komunikacyjne, podając przebieg lekcji prowadzonych według tych metod jak i cechy charakterystyczne takich jednostek lekcyjnych. W rozdziale tym Autorzy trafnie piszą, że najważniejszym celem zajęć z języka obcego jest osiągniecie przez uczącego się kompetencji komunikacyjnej. Niestety ujęli tę kwestię tylko w odniesieniu do lekcji języka angielskiego a nie innych języków obcych.

Szczególnej uwadze polecam rozdział 6 - Medien des Fremdsprachenunterrichts - (str. 93-108), w którym scharakteryzowano media w procesie nauczania języka obcego. Należy zaznaczyć, iż Autorzy słusznie podkreślają, że 
najważniejszym medium służącym porozumiewaniu się pomiędzy ludźmi jest i pozostanie język zarówno w formie ustnej, jak i pisemnej. W rozdziale tym przedstawiono media od tych starszych stosowanych na lekcji, tj. prasę, film, radio, telewizję aż po najnowsze, tj. elektroniczne środki komunikacji, jak komputer, poczta elektroniczna i Internet. Należy podkreślić, że nie pominięto przy tym roli podręcznika - jego wad i zalet oaz możliwości, jakie dają nowe media jako narzędzie pozwalające dotrzeć do wielu cennych źródeł informacji, a zarazem trudności, jakie mogą wystąpić podczas pracy z nimi.

Rozdział 7 - Interaktion im fremdsprachlichen Klassenzimmer - (str. 109-122) dotyczy m.in. problemu interakcji i jej typowych wzorców w dyskursie klasowym czy pozaszkolnym, specyfiki interakcji na lekcji języka obcego oraz wizji interaktywnej obcojęzycznej klasy. Rozdział ten polecam szczególnie początkującym nauczycielom, którzy chcą jak najwięcej dowiedzieć się o rozwoju językowym uczącego się zwłaszcza w sferze kompetencji komunikacyjnej związanej z realizacją języka w różnych rolach społecznych i układach interpersonalnych.

W rozdziale 8-Zwei Initiativen zur Jahrtausendwende Fremdsprachenunterricht in der Grundschule und Bilingualer Unterricht - (str. 127-139) Autorów interesuje problem nauczania języków obcych w szkole podstawowej. Opierając się na badaniach naukowych, poruszają oni ważny w dzisiejszych czasach globalizacji i wzajemnych kontaktów z przedstawicielami różnych kultur problem jak najwcześniejszego rozpoczynana nauki języków obcych oraz bilingwizmu już na etapie szkoły podstawowej.

Rozdział 9 - Europäische Sprachenpolitik und die Bildungsstandards in Deutschland - (str. 143-162) traktuje m.in. o koncepcjach rozwijania wielojęzyczności w niemieckich szkołach, europejskich ramach kwalifikacyjnych dla rozwoju języków obcych w szkolnictwie, wspomagających proces uczenia się języka obcego, częściach składowych i funkcjach europejskiego portfolio jezykowego oraz standardach rozwoju dla pierwszego języka obcego (języka angielskiego/języka francuskiego) w niemieckim szkolnictwie. Tę część pracy można potraktować jako lekturę uzupełniającą.

Za szczególnie cenny należy uznać rozdział 10 - Sprachliche Mittel funktional-kommunikativer Kompetenzen: Wortschatz und Grammatik - (str. 163-180) poświęcony nauczaniu i znaczeniu słownictwa oraz gramatyki na lekcji języka obcego. Uzyskamy tu odpowiedź na pytania, jak powinna wyglądać praca nad wprowadzaniem, utrwalaniem i poszerzaniem obcojęzycznego słownictwa. Bardzo ciekawa jest część, w której przedstawiono kwestię uczenia się języków obcych przy wykorzystaniu naszych zmysłów. Podano tu na przykład, ile materiału zapamiętujemy, a ile zapominamy, wykorzystując poszczególne zmysły. Nauczycieli zapewne zainteresuje podrozdział, w którym omówiono sposoby pracy nad słownictwem z wykorzystaniem technik 
mnemonicznych, np. podczas nauki ortografii. Nie pominięto przy tym problemu interferencji językowej w podsystemie leksykalnym. Autorzy przedstawiają także problem gramatyki na lekcji języka obcego, jej miejsce i rolę w procesie glottodydaktycznym, odpowiadają na pytanie, czym jest gramatyka, jak należy się jej uczyć i według jakich metod.

Przedmiotem rozdziału 11 - Fertigkeitsbezogene funktional-kommunikative Kompetenzen - (str. 181-204) są podstawy metodyczne w nauczaniu poszczególnych sprawności językowych, tj. sprawności słuchania, w tym słuchania ze zrozumieniem, czytania ze zrozumieniem, mówienia i pisania. Znajdziemy tu m.in. wskazówki, jak należy właściwie rozwijać i integrować sprawności na lekcji języka obcego, jak wyglądają zasady organizacji pracy nad kształtowaniem poszczególnych sprawności, jakie cechy powinny wyróżniać kompetentnego użytkownika języka sprawnie posługującego się tymi czterema sprawnościami. W tym kontekście poruszono problem oceniania i kontrolowania osiągnięć uczących się języków obcych. Autorzy próbują odpowiedzieć na pytanie, na czym polega prawidłowe testowanie poszczególnych sprawności i wchodzących w ich skład umiejętności, jak należy mierzyć wyniki uczących się, i na czym polegają kryteria właściwego oceniania.

Rozdział 12 - Methodische Kompetenzen - (str. 205-222) traktuje o kompetencjach metodycznych osób uczących się języków obcych. W rozdziale tym przedstawiono podział kompetencji, jakimi powinien dysponować uczący się, a także problem jego autonomii, kwestię świadomości językowej, stylów uczenia się, stosowanych przez niego strategii w procesie nauki języka i technik uczenia się. Warto podkreślić, iż Autorzy uwzględnili tutaj istotny w dzisiejszych czasach błyskawicznego rozwoju najróżniejszych technologii problem receptywnej i produktywnej kompetencji medialnej uczących się.

Bardzo ciekawy jest rozdział 13 - Interkulturelle Kompetenzen: interkulturelles Lernen - (str. 223-242), w którym scharakteryzowano interkulturowe tendencje we współczesnej glottodydaktyce, w tym m.in. kwestię kształcenia kompetencji interkulturowej, roli komponentu kulturowego w nauczaniu języka i wiedzy o krajach języka docelowego, związku języka z kulturą, historycznych aspektów kulturoznawstwa w edukacji szkolnej, roli kulturoznawstwa porównawczego oraz roli poruszanych na zajęciach treści. Autorzy słusznie podkreślają konieczność pojmowania kontaktu językowego nie tylko w znaczeniu konfrontacji systemów językowych, ale także kultur reprezentowanych przez dane języki.

Ostatni rozdział (rozdział 14) - Literarisch - ästhetische Kompetenzen: die Arbeit mit Literatur, Film, Comics, Bildern (str. 243-256) dotyczy tekstu na lekcji języka obcego, w tym roli tekstu literackiego. Moją uwagę zwróciły rady dotyczące kreatywnej pracy z tekstem i nad tekstem oraz sposoby kształtowa- 
nia umiejętności czytania przez uczniów tekstów literackich i rozwijania kompetencji literacko-estetycznej. Warto podkreślić, że Autorzy traktują tekst literacki jako drogę do nauczania interkulturowego. Sądzę, że ciekawą propozycją jest propozycja pracy na lekcji języka obcego z tekstem medialnym na przykład z komiksem czy filmem fabularnym.

Niniejsza publikacja nie opiera się na twierdzeniach i badaniach zaczerpniętych z jednej tylko dyscypliny naukowej. Praca ta w sposób interdyscyplinarny podchodzi do problemów związanych z procami uczenia się i nauczania języków obcych. Uważam, że stanowi ona istotne wzbogacenie istniejącej literatury przedmiotu i jest godna polecenia zarówno studentom, przygotowującym się do zawodu nauczyciela języka obcego, jak i nauczycielom-praktykom zainteresowanym stałym podnoszeniem efektywności kształcenia językowego swoich uczniów, a zarazem pragnącym podnieść własne kwalifikacje. Zachęcam nauczycieli języka niemieckiego do sięgania po tę publikację, ponieważ zawarte w niej wskazówki i informacje stanowią nie tylko praktyczną wiedzę w naszej codziennej pracy, ale również pomogą nam ustrzec się błędów merytorycznych, których popełniania często nie jesteśmy świadomi. 